\title{
Clinical biochemical and serological profile in Children with Celiac disease
}

\author{
Shrivastava V. ${ }^{1}$, Lohia P. ${ }^{2 *}$ \\ DOI: https://doi.org/10.17511/ijpr.2021.i03.01 \\ ${ }^{1}$ Vishal Shrivastava, Department of Pediatrics, People's College of Medical Sciences \& Research Centre, Bhopal, Madhya Pradesh, India. \\ 2* Purnendu Shekhar Lohia, Assistant Professor, Department of Paediatrics, People's College of Medical Sciences and Research Centre, \\ Bhopal, Madhya Pradesh, India.
}

\begin{abstract}
Background: Celiac disease $(C D)$ is a chronic, immunologically determined form of enteropathy affecting the small intestine, precipitated by the ingestion of gluten-containing foods such as wheat rye, barley etc. This study was taken up to analyze clinical manifestations and biochemical profile of children with celiac disease presenting at KEM Hospital Pune. Methods: All children diagnosed as CD in last 5 years and newly diagnosed patients of celiac satisfying inclusion criteria for next 1 year. This is an observational descriptive prospective and retrospective study. CD was diagnosed based on positive tTGA \& duodenal biopsy in children with chronic diarrhea \& other suggestive features. Hospital records were reviewed for complete follow up data. Results: In a study period of 12 months we diagnosed 19 children with Celiac Disease, who were studied prospectively, whereas 31 patients who were diagnosed within the last 6 years \& were on regular follow up in OPD were studied retrospectively. In the total group of 50 patients in the age range of 1 year to 15 years. The presenting clinical features of our group of patients were: chronic diarrhea (92\%), failure to thrive $(86 \%)$, abdominal pain (34\%), abdominal distention (26\%), anorexia/vomiting ( $8 \% / 20 \%)$, \& weight loss $(8 \%)$. Rare features were fever, fatigue, blood in stools \& constipation. In our study anemia was seen in $76 \%$ of patients, $58 \%$ of prospective patients had low ferritin levels. Conclusions: In a study period of 12 months we diagnosed 19 children with Celiac disease which goes to go prove that Celiac Disease, is not rare in western Maharashtra. Most patients belonged to the age group 1-5 years (50\%) and the majority of patients were females $(56 \%)$. Chronic diarrhea was the most common presenting complaint in all age groups ( $92 \%$ ) followed by failure to thrive, not gaining weight and abdominal pain. Constipation was least common. Anemia was the most common laboratory-confirmed finding and the most common type of anemia was iron deficiency anemia. Prevalence Anemia was most common in below 5 yrs.
\end{abstract}

Keywords: Celiac, Chronic diarrhea, Anemia

Corresponding Author

Purnendu Shekhar Lohia, Assistant Professor, Department of Paediatrics, People's College of Medical Sciences and Research Centre, Bhopal, Madhya Pradesh, India.

Email: drpslohia88@gmail.com

\section{How to Cite this Article}

Shrivastava V, Lohia PS. Clinical biochemical and serological profile in Children with Celiac disease. Pediatric Rev Int J Pediatr Res. 2021;8(3):121-129. Available From

https://pediatrics.medresearch.in/index.php/ijpr/arti cle/view/676
To Browse

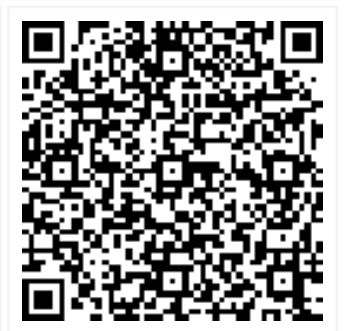

Manuscript Received 2021-05-02

Conflict of Interest No
Review Round 1 2021-05-12

Funding $\mathrm{Nil}$

Review Round 2
2021-05-22
Ethical Approval
Yes

Review Round 2

Yes
Review Round 3

Plagiarism X-checker $8 \%$
Accepted 2021-05-29

Note

(C) 2021 by Vishal Shrivastava, Purnendu Shekhar Lohia and Published by Siddharth Health Research and Social Welfare Society. This is an Open Access article licensed under a Creative Commons Attribution 4.0 International License https://creativecommons.org/licenses/by/4.0/ unported [CC BY 4.0]. 


\section{Introduction}

Celiac disease $(C D)$ is a chronic, immunologically determined form of enteropathy affecting the small intestine in genetically predisposed children and adults. It is precipitated by the ingestion of glutencontaining foods [1]. The prevalence of the celiac disease is globally $1 \%$, but large variations among countries have been shown [2]. There is a general perception that celiac disease is very uncommon in India. Recently there have been increasing reports from North India (major wheat eating areas) $[3,4]$.

Additionally, there is a gender difference. The incidence is twice as high in girls as in boys $[5,6]$. The gradual introduction of gluten-containing foods into the diet of infants while they are still being breastfed reduces the risk of celiac disease in early childhood and probably also during the subsequent childhood period $[7,8]$. The clinical features of CD can vary from being mild to severe and different organs can be affected. Gastrointestinal manifestations are common especially in younger children.

Common manifestations of this disease are chronic or intermittent diarrhea, failure to thrive, recurrent abdominal pain, cramping or distension and unexplained iron deficiency anemia. In older children and adults the symptoms vary from fatigue, anemia, infertility to depression $[9,10,11]$. Initial testing involves serologic markers that have a high predictive value in both children and adults [12]. The only treatment for celiac disease is strictly GFD for life [13].

No foods or medications containing gluten from wheat, rye, and barley or their derivatives can be taken, as even small quantities of gluten may be harmful. Complete removal of gluten from the diet of celiac disease patients will result in symptomatic, serologic, and histological remission in most patients [14]. In a recent report from Ludhiana, Sood et al. reported the prevalence of celiac disease to be 1 in 310 after a questionnaire-based survey of 4347 school children (aged 3-17 years) [15].

The prevalence of the disease in South India and Western India is largely unknown. This study was taken up to analyze clinical manifestations, biochemical profile and serology of children with celiac disease presenting at KEM Hospital Pune, which is a major gastroenterology centre in Western India and has an inflow of patients from all over Maharashtra.

\section{Material and Method}

Setting This study was conducted at K.E.M Hospital Pune which is a tertiary care centre and major pediatric gastroenterology centre of Maharashtra with many patients referred from the state and outside the state.

Subjects: All children diagnosed as $C D$ and satisfying inclusion criteria were enrolled in the study.

PART 1: Subjects included were those that presented to KEM Hospital, Pune during the study period.

PART 2: Subjects included those that had been diagnosed as CD since 2010 and who was on our Celiac registry $\&$ were on regular follow up.

\section{Study period}

01. Prospective -Newly diagnosed patients of celiac from 1st March 2015 to 28th Feb 2016.

02. Retrospective-Previously confirmed patients of celiac from 2010 onwards.

Study Design -Observational descriptive study

\section{Inclusion criteria}

01. All children presenting to Gastroenterology Department of K.E.M Pune with clinical features suspected* of celiac disease and confirmed by intestinal biopsy.

02. Consent

03. Age- 1 to $15 \mathrm{yrs}$

${ }^{*} \mathrm{CD}$ was suspected in patients presenting with the following symptomatology:

01. Chronic or intermittent diarrhea

02. Failure to thrive or faltering growth (in children)

03. Persistent or unexplained gastrointestinal symptoms including nausea and vomiting

04. Recurrent abdominal pain, cramping or distension

05. Sudden or unexpected weight loss

06. Unexplained iron-deficiency anemia

07. Type 1 diabetes mellitus

Exclusion criteria

01. Age $<1$ or $>15$ yrs

02. Non-consent

03. Not confirmed as celiac 
Retrospective study: All cases of confirmed celiac disease and those who were regularly attending OPD and diagnosed after 2010 were studied.

\section{Methodology of study}

Informed consent was taken from parents before the interview and inclusion of the study.

Clinical Examination: All patients were examined thoroughly for signs of anemia, lymphadenopathy, malnutrition, organomegaly, chest signs, murmur and CNS disease

\section{Investigations: Haemogram, Alanine} transaminase, Renal function tests, Prothrombin time, Serum electrolytes, Ionic calcium, Phosphorous, Alkaline phosphatase, Stool for Cryptosporidium. In addition for all newly diagnosed patients: Vitamin $\mathrm{D}(101)$ and serum ferritin (102) was done.

Immunology: Tissue transglutaminase (tTGA) quantitative estimation was done in each suspected patient and the following values following enzyme immunoassay (ELISA) method of the lab was used:

01. <20 IU-Negative

02. 20-30 IU-Weak positive,

03. >30IU-Positive

All suspected patients were subjected to intestinal biopsy following the flowchart proposed by WHO and the world gastroenterology association.

Figure 1. Flowchart used for the diagnosis of celiac disease

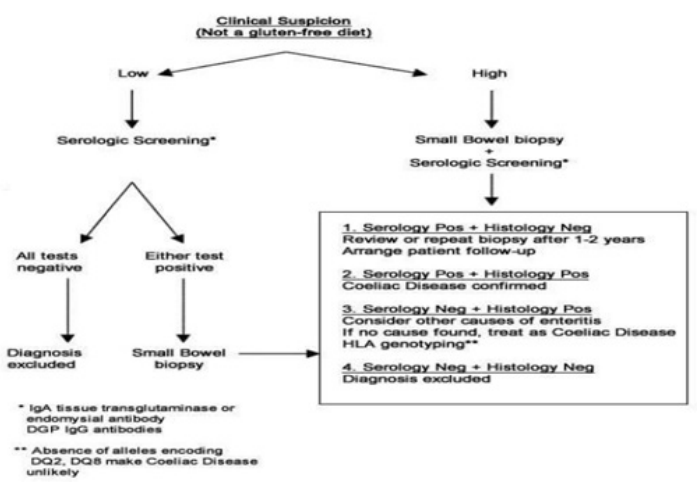

Biopsy technique: Endoscopic biopsy was done for all subjects following the above flowchart. Endoscopy was done in a specialized endoscopy unit under propofol anesthesia. For duodenal biopsy a small-diameter, flexible and fiberoptic endoscopes, Olympus GIF 140, GIF 150, PQ 20 were used.
Each endoscope had its specifications and use. Endoscopic visualization of the intestinal mucosa along with 4 biopsy specimen taken-three from the second part of the duodenum distal to the papilla, and one from the duodenal bulb. All samples were preserved in formalin and sent to KEM lab for histopathologic examination. The patient was observed inward for any complications following the biopsy.

\section{Results}

This study was done for one year from 26/2/2015 to $25 / 2 / 2016$. Children from age group 1 year to 15 years were included. In our study, we included 50 patients of whom 19 were diagnosed and followed up prospectively, while 31 were previously diagnosed patients of CD (since 2010), who were being followed up regularly in our OPD. Both these sets of patients are analyzed together. The following results were observed:

\section{Demographics}

Table 1. Age distribution of the cases studied with Celiac Disease $(n=50)$.

\begin{tabular}{|l|l|l|}
\hline \multicolumn{1}{|c|}{ Age Group (years) } & \multicolumn{1}{c|}{ No. of cases } & \multicolumn{1}{c|}{$\%$ of cases } \\
\hline Below 5.0 & 25 & 50.0 \\
\hline $5.0-10.0$ & 16 & 32.0 \\
\hline Above 10.0 & 9 & 18.0 \\
\hline Total & 50 & 100.0 \\
\hline
\end{tabular}

Values are $n$ (\% of cases).

Of the 50 cases studied, the majority were below age 5.0 years that is $25(50.0 \%), 16(32.0 \%)$ had their age between 5.0 - 10.0 years and 9 cases $(18.0 \%)$ had their age above 10.0 years. The mean \pm standard deviation of the age of the entire group was $\mathbf{5 . 9} \pm \mathbf{3 . 7}$ years. The youngest was diagnosed at 1.6 years while the oldest was 14 years.

Table 2. Gender Distribution of cases studied with Celiac Disease $(n=50)$.

\begin{tabular}{|l|l|l|}
\hline \multicolumn{1}{|c|}{ Sex } & \multicolumn{1}{c|}{ No. of cases } & \multicolumn{1}{c|}{ \% of cases } \\
\hline Male & 22 & 44.0 \\
\hline Female & 28 & 56.0 \\
\hline Total & 50 & 100.0 \\
\hline
\end{tabular}

Values are $\mathrm{n}$ (\% of cases).

Of the 50 cases studied, 22 (44.0\%) were males and $28(56 \%)$ were females. The male: female sex ratio was $0.8: 1.0$ in the entire study group. 
Table 3. Clinical features of the cases studied with Celiac Disease $(n=50)$.

\begin{tabular}{|l|l|l|}
\hline \multicolumn{1}{|c|}{ Clinical features } & No. of cases & \% of cases \\
\hline Chronic diarrhea & 46 & 92.0 \\
\hline Not gaining weight & 43 & 86.0 \\
\hline Abdominal Pain & 17 & 34.0 \\
\hline Abdominal distension & 13 & 26.0 \\
\hline Vomiting & 10 & 20.0 \\
\hline Weight loss & 5 & 10.0 \\
\hline Anorexia & 4 & 8.0 \\
\hline Other & 4 & 8.0 \\
\hline
\end{tabular}

Values are $n$ ( $\%$ of cases).

Of 50 cases studied, $46(92.0 \%)$ cases had chronic diarrhea, which thus is the most common clinical feature in our study, $43(86.0 \%)$ cases had complained of not gaining weight, $17(34.0 \%)$ cases had abdominal pain, $13(26.0 \%)$ cases had abdominal distension, $10(20.0 \%)$ had vomiting, 5 $(10.0 \%)$ cases had weight loss, 4 cases $(8.0 \%)$ had anorexia and $4(8.0 \%)$ cases had other features (One each -fever, blood in stools, fatigue and constipation). Constipation was least common. Diarrhea which lasts for more than 14 days, was non-infectious and associated with malabsorption was labelled as chronic diarrhoea.

Figure 2. Clinical features of the cases studied with Celiac Disease $(n=50)$.

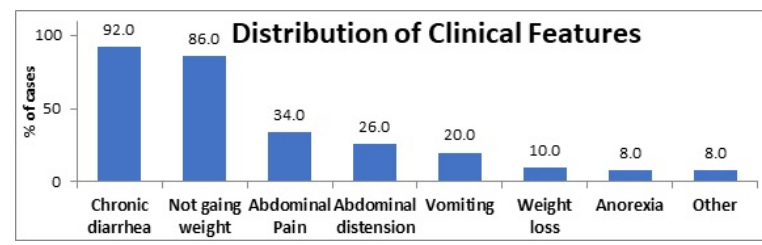

Table 4. Distribution of age group wise prevalence of clinical features of the cases studied with Celiac Disease $(n=50)$.

\begin{tabular}{|c|c|c|c|c|c|c|c|c|c|}
\hline \multirow[t]{3}{*}{ Clinical features } & \multicolumn{8}{|c|}{ Age Group (years) } & \multirow[t]{3}{*}{ P-value } \\
\hline & \multicolumn{2}{|c|}{ Below 5.0} & \multicolumn{2}{|c|}{$5.0-10.0$} & \multicolumn{2}{|c|}{ Above 10.0} & \multicolumn{2}{|c|}{ Total } & \\
\hline & $n$ & $\%$ & n & $\%$ & $\left.\right|^{n}$ & $\%$ & $n$ & $\%$ & \\
\hline Chronic diarrhea & 24 & 96.0 & 15 & 93.8 & 7 & 77.8 & 4 & 592. & $0.214 \mathrm{NS}$ \\
\hline Not gaining weight & 23 & 92.0 & 13 & 81.3 & 7 & 77.8 & 4 & 86. & $0.460 \mathrm{NS}$ \\
\hline Abdominal Pain & 3 & 12.0 & 10 & 62.5 & 4 & 44.4 & 1 & 34. & $0.003 * *$ \\
\hline Abdominal distension & 5 & 20.0 & 6 & 37.5 & 2 & 22.2 & 1 & 326. & $0.442 \mathrm{NS}$ \\
\hline Vomiting & 9 & 36.0 & 0 & 0.0 & 1 & 11.1 & 1 & 20. & $0.015 *$ \\
\hline Weight loss & 1 & 4.0 & 3 & 18.8 & 1 & 11.1 & 5 & 10. & $0.305 \mathrm{NS}$ \\
\hline Anorexia & 0 & 0.0 & 1 & 6.3 & 3 & 33.3 & 4 & 8.0 & $0.006 * *$ \\
\hline Other & 2 & 8.0 & 2 & 12.5 & 0 & 0.0 & 4 & 8.0 & $0.543 \mathrm{NS}$ \\
\hline
\end{tabular}

Values are $\mathrm{n}$ ( $\%$ of cases). P-value by Chi-Square test.
$P$-value $<0.05$ is considered to be statistically significant. *P-value $<0.05 * *$ P-value $<0.01, * * *$ Pvalue $<0.001$, NS: Statistically Non-Significant.

Distribution of age group wise prevalence of clinical features of the cases studied with Celiac Disease.

01 . The prevalence of chronic diarrhea did not differ significantly across the three age groups studied (P-value $>0.05)$.

02. The prevalence of not gaining weight did not differ significantly across the three age groups studied ( $P$-value $>0.05$ ).

03. The prevalence of abdominal pain differs significantly across the three age groups studied ( $P$-value $<0.01)$. This may be due to increased reporting in the older age group.

04. Prevalence of abdominal distension did not differ significantly across the three age groups studied (P-value $>0.05)$.

05. The prevalence of vomiting differs significantly across the three age groups studied ( $P$ value $<0.05$ ).

06. The prevalence of weight loss did not differ significantly across the three age groups studied (P-value $>0.05)$.

07. The prevalence of anorexia differs significantly across the three age groups studied ( $P$ value $<0.01$ ). This is a subjective finding and is assumed to be more reported in the older age group.

08. Prevalence of other clinical features (fever, blood in stool, fatigue and constipation) did not differ significantly across the three age groups studied ( $P$-value $>0.05$ ).

Table 5. Distribution of abnormal findings investigations at the time of diagnosis amongst the cases studied with Celiac Disease $(n=50)$.

\begin{tabular}{|l|l|l|l|}
\hline \multicolumn{2}{|c|}{ Investigations } & No. of cases & $\%$ of cases \\
\hline \multirow{3}{*}{ Hemoglobin } & Normal & 12 & 24.0 \\
\cline { 2 - 4 } & Anemia & 38 & 76.0 \\
\hline \multirow{3}{*}{ Siver Transaminase } & Normal & 45 & 90.0 \\
\cline { 2 - 4 } & Elevated & 5 & 10.0 \\
\hline Prothrombin Time & Normal & 49 & 98.0 \\
\cline { 2 - 4 } & Hypokalemia & 1 & 2.0 \\
\cline { 2 - 4 } & Normal & 49 & 98.0 \\
\hline Hypoalbuminemia & No & 43 & 2.0 \\
\hline
\end{tabular}




\begin{tabular}{|l|l|l|l|}
\hline \multirow{3}{*}{ iCa } & Yes & 7 & 14.0 \\
\hline \multirow{3}{*}{ Phosphorous } & Normal & 45 & 90.0 \\
\cline { 2 - 4 } & Low & 5 & 10.0 \\
\hline \multirow{3}{*}{ Alk Phosphate } & Normal & 45 & 90.0 \\
\cline { 2 - 4 } & Low & 5 & 10.0 \\
\hline \multirow{3}{*}{ ttool for Cryptosporidium } & Normal & 45 & 90.0 \\
\cline { 2 - 4 } & High & 5 & 10.0 \\
\hline \multirow{3}{*}{ RSG } & Negative & 43 & 86.0 \\
\cline { 2 - 5 } & Positive & 7 & 14.0 \\
\hline \multirow{3}{*}{ Vitamin D } & Non-Specific & 49 & 98.0 \\
\cline { 2 - 5 } & Hepatomegaly & 1 & 2.0 \\
\hline & Normal & 48 & 96.0 \\
\cline { 2 - 5 } & Elevated & 2 & 4.0 \\
\hline & Normal & 31 & 62.0 \\
\cline { 2 - 4 } & Deficient & 19 & 38.0 \\
\hline
\end{tabular}

Of 50 cases studied, 38 cases $(76.0 \%)$ were anemic (low hemoglobin), which was the most common lab abnormality.5 (10\%) had elevated Liver Transaminase, of which 1 child $(2 \%)$ had Hepatomegaly on USG. 1child (2.0\%) had Hypokalemia (Serum Electrolyte), 1child(2.0\%) had prolonged Prothrombin Time, 7(14.0\%) had Hypoalbuminemia, $5(10.0 \%)$ had low iCa, 5 (10.0\%) had low phosphorus, $5(10.0 \%)$ had high Alkaline Phosphatase. 7 children (14.0\%) had positive Stool for Cryptosporidium, 2 (4.0\%) cases had elevated urea and creatinine.

Figure 3. Distribution of abnormal findings investigations at the time of diagnosis among the cases studied with Celiac Disease $(n=50)$.

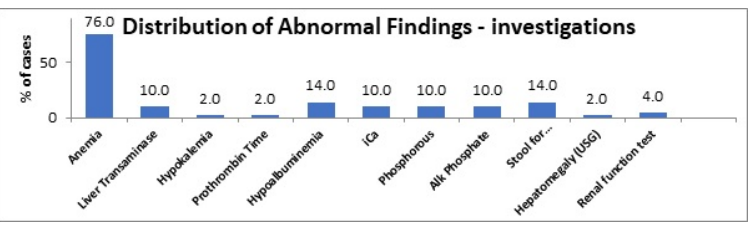

Table 6. Distribution of anemia according to various age groups of the cases studied with Celiac Disease $(\mathbf{n}=\mathbf{5 0})$.

\begin{tabular}{|c|c|c|c|c|c|c|c|}
\hline \multirow{2}{*}{$\begin{array}{c}\text { Age Group } \\
\text { (years) }\end{array}$} & \multicolumn{2}{|c|}{ Anemia } & \multicolumn{2}{|c|}{ Normal } & \multicolumn{2}{|c|}{ Total } & \multirow{2}{*}{ value } \\
\hline & $\begin{array}{l}\text { No. of } \\
\text { cases }\end{array}$ & $\begin{array}{l}\% \text { of } \\
\text { cases }\end{array}$ & $\begin{array}{l}\text { No. of } \\
\text { cases }\end{array}$ & $\begin{array}{l}\% \text { of } \\
\text { cases }\end{array}$ & $\begin{array}{l}\text { No. of } \\
\text { cases }\end{array}$ & $\begin{array}{l}\% \text { of } \\
\text { cases }\end{array}$ & \\
\hline Below 5.0 & 23 & 92.0 & 2 & 8.0 & 25 & 100.0 & $0.012 *$ \\
\hline $5.0-10.0$ & 11 & 68.8 & 5 & 31.3 & 16 & 100.0 & \\
\hline Above 10.0 & 4 & 44.4 & 5 & 55.6 & 9 & 100.0 & \\
\hline otal & 38 & 76.0 & 12 & 24.0 & 50 & 100.0 & \\
\hline
\end{tabular}

Values are $\mathrm{n}$ (\% of cases). P-value by Chi-Square test. P-value $<0.05$ is considered to be statistically significant. *P-value $<0.05$.
Prevalence of anemia differs significantly across three age groups of the cases with celiac disease studied ( $P$-value $<0.05)$. Anemia was most common in below 5 yrs(23 of 25 cases) and least common above 10 yrs of age (4 of 9 cases) in our study though in all age group anemia was a significant finding. Table 6

Table 7. Distribution of the cases studied with Celiac Disease according to serum ferritin $(n=19)$.

\begin{tabular}{|l|l|l|}
\hline \multicolumn{1}{|c|}{ Serum ferritin level $(\boldsymbol{\mu g} / \mathrm{I})$} & No. of cases & \% of cases \\
\hline Deficiency & 11 & 57.9 \\
\hline Sufficiency & 8 & 42.1 \\
\hline Total & 19 & 100.0 \\
\hline
\end{tabular}

Values are $n$ (\% of cases).

Ferritin levels were done in all prospective cases. Ferritin levels of $<12 \mu \mathrm{g} / \mathrm{l} \quad(<5 \mathrm{yrs})$ and $<15$ $\mu \mathrm{g} / \mathrm{l}$ (>5years) was taken as deficient [16]. Of the total 19 cases investigated for Ferritin deficiency, 11 (57.9\%) had a deficiency, 8 (42.1\%) had sufficiency indicating that iron deficiency anemia was the most common anemia in $\mathrm{CD}$.

Table 8. Distribution of the cases studied with Celiac Disease according to vitamin D deficiency $(n=19)$.

\begin{tabular}{|l|l|l|}
\hline Vitamin D Deficiency Status $(\mathrm{ng} / \mathrm{ml})$ & No. of cases & $\%$ of cases \\
\hline Severe Deficiency $(<5)$ & 2 & 10.5 \\
\hline Deficiency $(5-20)$ & 14 & 73.7 \\
\hline Sufficiency $(>20)$ & 3 & 15.8 \\
\hline Total & 19 & 100.0 \\
\hline
\end{tabular}

Values are $\mathrm{n}$ (\% of cases).

Vitamin D levels were done in all prospective cases. Vitamin D levels were classified as: Severe Deficiency $(<5)$, Deficiency $(5-20)$, Sufficiency (>20) as per Indian reference data(101). Of 19 cases investigated for Vit D deficiency, 2 (10.5\%) had a severe deficiency, 14 (73.5\%) had a deficiency and $3(15.8 \%)$ had a sufficiency. This suggests that vitamin $D$ deficiency was an important laboratory finding in $C D$.

\section{Serology}

Table 9. Distribution of the cases studied with Celiac Disease according to levels of TGA $(\mathbf{n}=\mathbf{5 0})$.

\begin{tabular}{|l|l|l|}
\hline \multicolumn{1}{|c|}{ TGA Levels } & No. of cases & \multicolumn{1}{c|}{$\%$ of cases } \\
\hline$<20$ (Negative) & 8 & 16.0 \\
\hline $20-30$ (Weak Positive) & 2 & 4.0 \\
\hline$>30$ (Positive) & 40 & 80.0 \\
\hline
\end{tabular}


Total

50

100.0

Values are $\mathrm{n}$ ( $\%$ of cases).

Of the 50 cases studied, the majority of cases studied 40 cases $(80.0 \%)$ had Positive tTGA, only 2 cases $(4.0 \%)$ had weak positive tTGA and 8 cases $(16.0 \%)$ had negative tTGA. This suggests that tTGA levels have good sensitivity but negative tTGA does not rule out Celiac Disease, though positive tTGA strongly supports CD.

Table 10. Descriptive statistics of tTGA in Celiac Disease patients $(\mathbf{n}=\mathbf{5 0})$.

\begin{tabular}{|l|l|l|l|l|c|}
\hline Parameter & $\begin{array}{c}\text { No. of } \\
\text { cases }\end{array}$ & Mean & $\begin{array}{r}\text { Standard } \\
\text { Deviation }\end{array}$ & Median & $\begin{array}{c}\text { Min - } \\
\text { Max }\end{array}$ \\
\hline $\begin{array}{l}\text { tTGA IgA } \\
(\mathrm{U} / \mathrm{mL})\end{array}$ & 50 & 131.84 & 89.14 & 141.50 & $3.0-300.0$ \\
\hline
\end{tabular}

Values are Descriptive Statistical Measures.

The mean value of tTGA was 131.84 and the Median was 141.50 indicating the importance of high tTGA titres in $C D$.

\section{Discussion}

This study was a prospective and retrospective observational study conducted at a pediatric gastroenterology unit of a tertiary care hospital. The total number of children diagnosed with the Celiac disease was 50, who were followed after 1,3,6 months in a prospective study and single follow up in the retrospective study. All enrolled patients were assessed at admission and their clinical parameters were noted and patients were followed up as per proforma.

Among 50 biopsy-proven CD children and adolescents, various age-related characteristics were detected.

\section{Demographic data}

Age: In this study majority of patients belonged to the age group $<5 y$ rs $(50 \%)$, followed by the age group 5-10 yrs (32\%). The mean \pm standard deviation (SD) of the age of the entire group was $5.9 \pm 3.7$ years as in a study by Poddar et al. where the mean age at diagnosis 6.3 to 8.6. In the study by Stone et al [17]. infants less than 2 years of age represented only $12 \%$ of the study, $27 \%$ of patients were aged between 4 and 5 years, 36\% were aged between 5 and 10 years and 26\% were more than 10 years of age. Lower age at diagnosis suggest improved awareness for celiac disease among pediatricians and improved availability of serological tests [18].
Gender: Amongst the study population, 56 were males and 44 females, which was similar to the study in the west by Wingren et al [19]. In another study by Singh et al. there was female predominance. Stone et al [17]. had a similar observation. A simple explanation for this gender difference is elusive but may relate to dissimilar hormonal and immune responses to injury and inflammation in the presence of gluten introduction; related gender differences have been observed in other immune system-mediated disorder. [20,21].

Clinical manifestations: Regarding the clinical manifestations, chronic diarrhea was the most common clinic manifestation (92\%) overall in all age groups which was similar to the study done by Poddar et al. and by Mohindar et al [22]. where chronic diarrhea was observed at $88 \%$ and $86 \%$ respectively. Stone et al. [17]. in his study showed the most common presenting symptom in younger children (those $<5$ years) was diarrhea (59\%), followed by irritability (34\%) and weight loss $(38 \%)$. In older children ( $\geq 5$ years), the most common presenting feature was abdominal pain (55\%) followed by diarrhea (26\%). In our study not gaining weight was noted in $86 \%$ of which was $45 \%$ as reported by Tanpowpong et al [18]. In our study abdominal pain was seen in $17 \%$ and $13 \%$ of the study population had abdominal distension which was mainly seen in school-aged and adolescence while abdominal pain and abdominal distension was reported to be $45 \%$ and $9 \%$ respectively by Tanpowpong et al. [18]. In our study constipation was seen in $2 \%$ of children while it was seen in $20 \%$ of children in a study by Tanpowpong et al [18]. This observation was similar to that reported by Sharma et al. [23]. and Rashid et al [24]. In our study $10 \%$ of children had vomiting while it was seen in $20 \%$ of the study population by Tanpowpong et al [18]. Vomiting was seen in $24 \%$ of children in a study by Stone et al [17]. These all disparities might be because of various reporting and/or referral issues by the caregivers and healthcare providers, a possibility that requires further investigation. Generally, the younger children could likely have limited capability to express subjective symptoms when compared with the older individuals. Natural courses, environmental factors (e.g., breastfeeding and gluten 8introduction), and disease pathogenesis could be different between younger and older children. $184 \%$ of our cases had a positive family history in 1st-degree relatives while in the study Tanpowpong et al [18]. it was $19 \%$. 
The significant age-related differences in the family history of $C D$ were interesting but difficult to explain. School-aged children and adolescents, who were more likely to have no or less typical CD symptoms, might also be more likely to undergo $C D$ screening solely because of positive family members with $C D$ compared with the younger children.

A similar reason might explain the borderline significant higher proportion of family history of irritable bowel syndrome among school-aged children as well. Another possible explanation might be because of differences in parental or patient reports across the age groups. These questions will need to be addressed with future research.

Anemia was present in $76 \%$ of the study population $(n=50)$ which was similar to the study of Poddar et al and Mohindar et al [22]. In the study by Stone et al [17]. anemia was seen only in $21 \%$ of the study population. In our study percentage of iron deficiency anemia was $58 \%$ (the number was less in patients $(n=19)$ in confirmed iron deficiency because of the unavailability of ferritin values in the retrospective study population).

Laboratory parameters: $10 \%$ of the study population had elevated transaminases, $4 \%$ had abnormal renal function tests, $2 \%$ had hypokalemia, $14 \%$ had hypoalbuminemia, $2 \%$ had elevated prothrombin time, $10 \%$ had low ionic calcium, low phosphorous and high alkaline phopthatase. $14 \%$ of our study children were positive for stool cryptosporidium which was similar to study by Fassano et al [25]. and Tanpowpong et al [18] Vitamin D deficiency was found in $14(73.7 \%)$ and severe deficiency was found in $2(10.5 \%)$ of 19 patients in the prospective study population while in a study by Villanueva et al [26]. it was $27.5 \%$.

USG was non-specific in the present study and did not appear to have a role in celiac disease diagnosis which is against the study by Recabbona et al [27]. in which various sonographic anomalies in children with Celiac disease were observed: abdominal fluid in $76 \%$, hyperperistalsis in $82 \%$, pericardial effusion in $47 \%$ and unusual appearance of the small bowel wall in $94 \%$.

This might be a subjective finding and needs further studies to validate the role of USG and standardize USG criteria for $C D$. In our study the mean tTGA value was $131.84 \mathrm{U} / \mathrm{ml}$ which was similar to the study by Dogan et al [28].
Limitations: This study has some potential limitations. A part of the study was conducted in a retrospective fashion at a large teaching hospital.

Although we acknowledge the possibility of incomplete information, both recall and information biases as well as the inability to control for all of the parent- or patient-reported data with the physicians' interpretation, we believe that our novel findings will provide a platform for the development of agerelated approaches for evaluation and management of $C D$.

\section{Conclusion}

In a study period of 12 months we diagnosed 19 children with Celiac disease which goes to go prove that $C D$ is not rare in western Maharashtra. In the present study, maximum patients out of 50 enrolled patients belonged to the age group 1-5 years $(50 \%)$.

The majority of patients were females (56\%). Chronic diarrhea was the most common presenting complaint in all age groups (92\%) followed by failure to thrive, not gaining weight and abdominal pain. Constipation was least common.

Anemia was the most common laboratory-confirmed finding and the most common type of anemia was iron deficiency anemia. Vit $D$ deficiency was also more common in $\mathrm{CD}$ than in the general population $(84 \%)$. The majority of cases studied $(80 \%)$ had Positive tTGA indicating its importance in the screening of $C D$.

\section{What does the study add to the existing knowledge?}

- Contrary to the general belief Celiac disease is not rare in western Maharashtra.

- Age-wise prevalence of symptoms in children with Celiac disease.

- Diagnosis should be confirmed only on positive duodenal biopsies \& supportive serology (tTGA). Early referral for endoscopic duodenal biopsy if serological studies are positive is recommended.

\section{Declarations}

\section{- Funding: None}

- Conflict of interest: None declared

- Ethical approval: The study was approved by the institutional ethical committee. 


\section{Reference}

01. Ludvigsson JF, Leffler DA, Bai JC, Biagi F, Fasano $A$, Green $\mathrm{PH}$, et al. The Oslo definitions for coeliac disease and related terms. Gut. 2013 Jan;62(1)4352. doi: 10.1136/gutjnl-2011-301346 [Crossref] [PubMed][Google Scholar]

02. Lionetti E, Catassi C. New clues in celiac disease epidemiology, pathogenesis, clinical manifestations, and treatment. Int Rev Immunol. 2011 Aug;30(4)219-31. doi: 10.3109/08830185.2011.602443 [PubMed][Google Scholar]

[Crossref]

03. Sood A, Midha V, Sood N, Kaushal V, Puri H. Increasing incidence of celiac disease in India. Am J Gastroenterol. 2001 Sep;96(9)2804-5. doi: 10.1111/j.1572-0241.2001.04150.x [Crossref] [PubMed][Google Scholar]

04. Sood A, Midha V, Sood N, Avasthi G, Sehgal A. Prevalence of celiac disease among school children in Punjab, North India. J Gastroenterol Hepatol. 2006 Oct;21(10)1622-5. doi: 10.1111/j.14401746.2006.04281.x [Crossref][PubMed][Google Scholar]

05. Wingren CJ, Agardh D, Merlo J. Sex differences in coeliac disease risk- a Swedish sibling design study. Dig Liver Dis. 2012 Nov;44(11)909-13. doi: 10.1016/j.dld.2012.06.016 [Crossref][PubMed] [Google Scholar]

06. Ivarsson A, Persson LA, Nyström L, Hernell O. The Swedish coeliac disease epidemic with a prevailing twofold higher risk in girls compared to boys may reflect gender specific risk factors. Eur J Epidemiol. 2003;18(7)677-84. doi: 10.1023/a:1024873630588 [Crossref][PubMed] [Google Scholar]

07. Ivarsson A, Hernell O, Stenlund H, Persson LA. Breast-feeding protects against celiac disease. Am J Clin Nutr. 2002 May;75(5)914-21. doi: 10.1093/ajcn/75.5.914 [Crossref][PubMed][Google Scholar]

08. Myléus A, Hernell O, Gothefors L, Hammarström $M L$, Persson LA, Stenlund $H$, Ivarsson A. Early infections are associated with increased risk for celiac disease- an incident case-referent study. BMC Pediatr. 2012 Dec 19;12;194. doi: 10.1186/14712431-12-194 [Crossref][PubMed][Google Scholar]
09. Ludvigsson JF, Ansved $\mathrm{P}$, Fälth-Magnusson $\mathrm{K}$, Hammersjö JA, Johansson C, Edvardsson $S$, Ljungkrantz $M$, Stenhammar $L$, Ludvigsson $J$. Symptoms and signs have changed in Swedish children with coeliac disease. J Pediatr Gastroenterol Nutr. $2004 \quad$ Feb;38(2)181-6. doi: 10.1097/00005176-200402000-00015 [Crossref] [PubMed][Google Scholar]

10. Fasano A. Clinical presentation of celiac disease in the pediatric population. Gastroenterology. 2005 Apr;128(4 Suppl 1)S68-73. doi: 10.1053/j.gastro.2005.02.015 [Crossref][PubMed] [Google Scholar]

11. McGowan KE, Castiglione DA, Butzner JD. The changing face of childhood celiac disease in north america- impact of serological testing. Pediatrics. 2009 Dec;124(6)1572-8. doi: 10.1542/peds.20082373 [Crossref][PubMed][Google Scholar]

12. Husby $\mathrm{S}$, Koletzko $\mathrm{S}$, Korponay-Szabó IR, Mearin ML, Phillips A, Shamir R, et al. European Society for Pediatric Gastroenterology, Hepatology, and Nutrition, European Society for Pediatric Gastroenterology, Hepatology, and Nutrition guidelines for the diagnosis of coeliac disease. J Pediatr Gastroenterol Nutr. 2012 Jan;54(1)136-60. doi: 10.1097/MPG.0b013e31821a23do [Crossref] [PubMed][Google Scholar]

13. Holtmeier W, Caspary WF. Celiac disease. Orphanet J Rare Dis. 2006 Mar 1;1;3. doi: 10.1186/1750-1172-1-3 [Crossref][PubMed][Google Scholar]

14. Marsh MN. Gluten, major histocompatibility complex, and the small intestine- A molecular and immunobiologic approach to the spectrum of gluten sensitivity ('celiac sprue'). Gastroenterology. 1992 Jan;102(1)330-54. [Crossref][PubMed][Google Scholar]

15. Sood A, Midha V, Sood N, Kaushal V, Puri H. Increasing incidence of celiac disease in India. Am J Gastroenterol. 2001 Sep;96(9)2804-5. doi: 10.1111/j.1572-0241.2001.04150.x [Crossref] [PubMed][Google Scholar]

16. Worwood M. "Indicators of the iron status of populations- ferritin". Assessing the iron status of populations- report of a joint World Health Organization/Centers for Disease Control and Prevention technical consultation on the assessment of iron status at the population level 2. 2007;35-74. [Crossref][PubMed][Google Scholar] 
17. Stone ML, Bohane TD, Whitten KE, Tobias VH, Day AS. Age related clinical features of childhood coeliac disease in Australia. BMC Pediatr. 2005 May 21;5(1)11. doi: 10.1186/1471-2431-5-11 [Crossref][PubMed][Google Scholar]

18. Tanpowpong $\mathrm{P}$, Broder-Fingert $\mathrm{S}$, Katz $\mathrm{AJ}$, Camargo CA Jr. Age-related patterns in clinical presentations and gluten-related issues among children and adolescents with celiac disease. Clin Transl Gastroenterol. 2012 Feb 16;3(2)e9. doi: 10.1038/ctg.2012.4 [Crossref][PubMed][Google Scholar]

19. Wingren CJ, Agardh D, Merlo J. Sex differences in coeliac disease risk- a Swedish sibling design study. Dig Liver Dis. 2012 Nov;44(11)909-13. doi: 10.1016/j.dld.2012.06.016 [Crossref][PubMed] [Google Scholar]

20. Whitacre CC, Reingold SC, O'Looney PA. A gender gap in autoimmunity. Science. 1999 Feb $26 ; 283(5406) 1277-8$. doi:

10.1126/science.283.5406.1277

[PubMed][Google Scholar]

[Crossref]

21. Nussinovitch $U$, Shoenfeld $Y$. The role of gender and organ specific autoimmunity. Autoimmun Rev. 2012 May;11(6-7)A377-85. doi: 10.1016/j.autrev.2011.11.001 [Crossref][PubMed] [Google Scholar]

22. Mohindra S, Yachha SK, Srivastava A, Krishnani N, Aggarwal R, Ghoshal UC, et al. Coeliac disease in Indian children- assessment of clinical, nutritional and pathologic characteristics. J Health Popul Nutr. 2001 Sep;19(3)204-8. [Crossref][PubMed][Google Scholar]
23. Mohandas KM. Surveillance of Indians with liver cirrhosis for treatable hepatocellular carcinomaanother enigma. Indian J Gastroenterol. 2007 NovDec;26(6)261-4. [Crossref][PubMed][Google Scholar]

24. Rashid M, Cranney A, Zarkadas M, Graham ID, Switzer C, Case S, Molloy M, Warren RE, Burrows V, Butzner JD. Celiac disease: evaluation of the diagnosis and dietary compliance in Canadian children. Pediatrics. 2005 Dec;116(6)e754-9. doi: 10.1542/peds.2005-0904 [Crossref][PubMed] [Google Scholar]

25. Fasano A, Catassi C. Current approaches to diagnosis and treatment of celiac disease- an evolving spectrum. Gastroenterology. 2001 Feb;120(3)636-51. doi: 10.1053/gast.2001.22123 [Crossref][PubMed][Google Scholar]

26. Villanueva J, Maranda L, Nwosu BU. Is vitamin D deficiency a feature of pediatric celiac disease?. J Pediatr Endocrinol Metab. 2012;25(5-6)607-10. doi: 10.1515/jpem-2012-0048 [Crossref][PubMed] [Google Scholar]

27. Riccabona M, Rossipal E. Bedeutung der Sonographie in der Diagnostik der Zöliakie [Value of ultrasound in diagnosis of celiac disease]. Ultraschall Med. 1996 Feb;17(1)31-3. doi: 10.1055/s-20071000451 [Crossref][PubMed][Google Scholar]

28. Dogan G, Ayhan S, Yilmaz B, Appak Y Ç, Dündar $P$ E, Ecemis $T$, et al. Relationship Between Duodenal Histopathology and Strong Positive Tissue Transglutaminase Antibodies in Children with Celiac Disease. Güncel Pediatri. 2015;13(3). [Crossref] [PubMed][Google Scholar] 